Turkish Studies - Historical Analysis

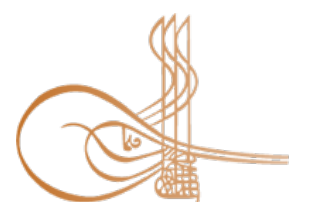

www.turkishstudies.net/history
eISSN: 2667-5552

Research Article / Araştırma Makalesi

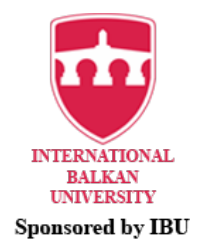

Sponsored by IBU

\title{
Osmanlı Tarihinde Gerçekleştirilememiş Bir Sergi Teşebbüsü: 1894 Dersaadet Ziraat ve Sanayi Sergi-i Umumisi Hazırlıkları
}

\author{
An Unrealized Exhibition Organization Attemt in Ottoman History: Preparations for Dersaadet \\ (İstanbul) Agricultural and Industrial Exposition in 1894
}

\author{
Turgut Karaçoban*
}

\begin{abstract}
The concepts of "fairs" or "exhibition" work have become valuable indicators, especially with the industrial revolution. Great states holding high power and influence in their times have taken these fairs for exhibiting their growth and strengths. Through these places, the newly industrialized states were looking for new markets by introducing their increased production and production goods. In the world, which gradually began to globalize, fairs began to turn into universal exhibitions presenting the dimensions of the development achieved. France has been a leading country which had taken the first step for building fairs as trade show marketings. In France, all fairs organized between 1798 and 1849 formerly hosted the exhibitions at the national level, and are considered the ancestors of international fairs. In addition to the countries such as America, France, Spain, Portugal and Russia, the Ottoman Empire participated in this fair in London. The Ottoman Empire also participated in this fair because it aimed to reveal the success of the state in fields of agriculture, art and industry and of the Sultan's share in these achievements. The first fair in the Ottoman Empire was held in 1863 during the reign of Sultan Abdulaziz. The exhibition has been opened in the Horse Square under the name of "Sergi-i Umûmî-i Osmanî" based on the fairs participated and experienced before. After the first exhibition, efforts to organize a new fair would have risen precisely thirty years later. This work includes the first fair organizing efforts in Ottoman State, including the preparatory works, the reasons for failing in such attempts and all required knowledge about the world fairs held until then.
\end{abstract}

Structured Abstract: Europe embarked on advertising activities to find new markets for production goods, which increased with industrialization and therefore focused on exhibiting its products after the 1850s. Twelve exhibitions held in France between the years 1798 and 1849 are regarded as pioneers of international exhibitions, even if they have been planned for national goals (Yllmaz, 2005: 719). Thanks to pioneering initiatives in France, these exhibitions, which aim to increase the commercial potential by displaying all kinds of products, have gained an international character since the mid-19th century. (Keskin, 2005: 203).

The Ottoman State participated in the London Fair in 1851, which was the first International Exhibition, with countries such as America, France, Spain, Portugal and Russia. Ottoman part of the exhibition had a pavilion resembling a fountain and covered with a cloth-like a tent was established, all the products were displayed in the showcases. Bursa silk was the product that attracted the most attention in the exhibition (Göğuss, 2007: 38) However, while technological inventions and industrial machines were exhibited in the booths of the

\footnotetext{
* Sakarya Üniversitesi Sosyal Bilimler Enstitüsü Tarih Bölümü Doktora Öğrencisi

Sakarya University,Institute of Social Sciences,Programs of History Phd

ORCID 0000-0002-3627-0200

turgutkaracoban@hotmail.com

Cite as/ Atıf: Karaçoban, T. (2020). Osmanlı tarihinde gerçekleștirilememiş bir sergi teşebbüsü: 1894 Dersaadet

Ziraat ve Sanayi Sergi-i Umumisi hazırlıkları. Turkish Studies - History, 15(2), 531-543. https://dx.doi.org/10.29228/TurkishStudies.40352

Received/Geliş: 30 December/Aralık 2019

Accepted/Kabul: 20 June/Haziran 2020

Copyright (C) INTAC LTD, Turkey

Checked by plagiarism software

Published/Yayın: 25 June/Haziran 2020

CC BY-NC 4.0
} 
Western countries, nothing new appeared in the stands of the Ottoman State other than traditional handicrafts, agricultural products and various raw materials (Ergüney and Pilehvarian, 2015: 228).

Taking into account the examples in Europe, the Ottoman State leads the opening of an exhibition in Istanbul (Demir, 2018: 156). During the reign of Sultan Abdülaziz, in 1863, the Ottoman State organized an exhibition called "Sergi-i Umûmî-i Osmanî" held at the Istanbul Horse Square by modelling the exhibitions that he had previously attended and gained experience. French architects Marie-Augustin-Antonie Bourgeois and Leon Prvillee designed the exhibition structures (Ergüney and Pilehvarian, 2015: 229).

More than ten thousand products consisting of industry, agriculture, weaving, leather and furniture brought from many provinces and districts of the Empire for the exhibition were exhibited in thirteen separate sections (Haz. Işı1kl1, 2012: 34). The exhibition opened by Sultan Abdülaziz remained open for five months and closed in July 1863. According to estimates, approximately one hundred or one hundred and fifty thousand people visited the exhibition (Keskin, 2005: 204).

The Ottoman State participated in the Paris World Fair opened in 1867. Sultan Abdülaziz personally participated in the opening of the exhibition upon the invitation from Napoleon, the Emperor of France. The fair is the first world exhibition attended by the Ottoman Empire at the reign level, and an Ottoman sultan went out of the nation for the first time. Russian Tsar, Emperor of Austria, Belgium, Portugal, Sweden, Prussian Kings and Prince of Wales also came to Paris for the exhibiton. Şehzade Murad, Abdülhamid and Yusuf İzzeddin attended on Sultan Abdülaziz's journey (Yılmaz, 2005: 723-724).

In order to exhibit at the Paris World Fair, the message was sent all over the country to transfer the most distinguished local and agricultural products to Istanbul. In a short period, the state managed to prepare 327 containers and two boats full of industrial and agricultural products for sending to the exhibition. Ottoman pavilion had several sections, mostly consisting of items sent by Egypt. Several building types that reflect the cultural and social life of the Ottoman, mosque, Boğaziçi mansion, bath and fountain prototypes were presented to the visitors (Tekdemir, 2013: 9-15). It seems that historical references and traditions appear to be taken into account in the preparation of the pavilions. (Çelik, 2005: 69). The products exhibited in this fair as representative elements of the Ottoman State consist of carpets, gold-coated fabrics, luxury furniture, raw processed silk, weapons, shoemaker, silver, iron and copper. In this exhibition, the Ottoman Empire won about 100 medals and honourable mentions (Ergüney and Pilehvarian, 2015: 231). It is accepted as a significant award that Egyptian cotton gains first place in the agricultural products competition (Tekdemir, 2013: 15).

Abdülhamid II ages was a period when exhibitions kept their importance. The chambers of commerce established during this period also paid particular attention to exhibitions for the development of the dormitory. This understanding stimulated Europe's desire to increase economy, employment and production activities throughout the country in the Ottoman Empire, which he called "sick man". The Ottoman State attached importance to international exhibitions politically as well as economically. The Paris exhibition in 1889 was considered crucial for international convergence and peace. Again II. Abdülhamid's positive approach to the 1893 Chicago Exhibition was also due to this perspective. II. Abdulhamid regarded such exhibitions as essential venues for image creation. For this reason, the State took care to participate in all exhibition participations, except that they could not participate for economic and political reasons.

For this purpose, Abdülhamit II gave the order to realize the second big exhibition in Istanbul after 1863 "Sergi-i Umûmî-i Osmanî" in order to "promote the development of the wealth and prosperity of the country". (Haz.ışıkl of 2012: 134). For this reason, a commission was established in 1893 to organize the exhibition under the name of "Dersaâdet Ziraat ve Sanâyi Sergi-i Umûmîsi". Selim Melhame is appointed as the chairman of the commission. The commission is elected by the Forest and Ma'âdin and Agriculture Ministry, under the supervision of Selim Melhame, namely Selim Melhame.

Selim Melhame, one of the names trusted by Abdülhamid II, carried out studies in line with the will of the sultan, prepared reports for the provision of material resources for the exhibition and presented them to the relevant institutions. II. The preparations for the exhibition, which Abdulhamid closely followed, were cancelled due to the 1894 Istanbul earthquake. The most significant achievement of this exhibition is Architect Raimondo D'Aronco, who has worked to repair the destruction of the earthquake and has been very successful.

Keywords: Fair, Exhibition, Ottoman, Selim Melhame 
Öz: "Fuar" ya da "Sergi” çalışması kavramları özellikle sanayi devrimiyle etkin birer gösterge haline gelmişlerdir. Zamanın büyük devletleri için uluslararası fuarlar, gelişmişliğin ve gücün sergilendiği mekanlardır. Sanayileşmiş Devletler, bu mekanlar aracılığıyla, artan üretimlerini ve üretim mallarını tanıtarak kendilerine yeni pazarlar arıyorlardı. Yavaş yavaş küreselleşmeye başlayan dünyada fuarlar, varılan ilerlemelerin boyutlarının gösterildiği evrensel sergilere dönüşmeye başlar. Bu konuda atılan adımların ilk ayak sesleri Fransa'da duyulmaya başlanır. Fransa'da, 1798 ile 1849 yılları arasında düzenlenen fuarlar başlangıçta ulusal düzeyde sergilere ev sahipliği yapsalar da uluslararası fuarların da atası sayılırlar. Dünya fuarı niteliğindeki ilk Fuar, 1851 yılında İngiltere'de düzenlenmiştir. Londra'daki bu fuara Amerika, Fransa, İspanya, Portekiz, Rusya gibi ülkelerin yanı sıra Osmanlı Devleti de katılmıştır. Osmanlı Devleti de bu fuara katılmıştır çünkü devletin tarım, sanat ve sanayideki başarıları ve padişahın bu başarılardaki payı ortaya konulmak istenmiştir. Osmanlı Devleti'nde ilk fuar Sultan Abdülaziz döneminde, 1863'te düzenlenmiştir. Sergi, daha önce katılınan ve deneyimlenen fuarlar model alınarak "Sergi-i Umûmî-i Osmanî " adıyla İstanbul At Meydanı'nda açılmıştır. Bu fuarda önceleri yerel ürünlerin sergilenmesi amaçlanmışsa da sonraları fuarın kapsamının genişletilmesi düşünülmüş, bu nedenle uluslararası nitelik kazandırılma hedefi güdülmüştür. İstanbul'daki ilk serginin ardından, tam otuz yıl sonra yeni bir fuar düzenleme çabaları görülür. Çalışmamız bu çabaları, bu fuar için yapılan hazırlık çalışmalarını ve fuarın yapılamama nedenlerini, ayrıca o zamana kadar gerçekleştirilen dünya fuarları hakkındaki bilgileri içermektedir."

Anahtar Kelimeler: Fuar, Sergi, Osmanl, Selim Melhame

İngiltere'de 18. yüzyılın ikinci yarısında başlayıp 19. yüzyılda tüm Avrupa'ya yayılan ekonomik gelişmeler, sanayi devrimin doğuşuna zemin hazırlamıştır. Sonrasında ise sanayi devrimi ekonomik bir devrim olarak başta Avrupa olmak üzere dünyayı oldukça geniş bir açıdan etkilemiş ve ortaya çıkan yeni Avrupa, devrim öncesinden çok farklı bir görünüm kazanmıştır(Yetişgin,2014:259). Avrupa'nın çehresini birdenbire değiştiren sanayi devriminin hazırlayıcı unsurları olarak: Avrupa'daki nüfus patlamasını, genişleyen tarımsal temelleri, trenlerle buharlı gemilerin ortaya çıkışını ve yaygınlaşmasını göz ardı edemeyiz.

$\mathrm{Bu}$ hazırlayıc1 etkenlerle birlikte meydana gelen sanayi devrimi Batı Avrupa'da bankacılık ve kredi kurumlarının gelişmesine sebep olacaktır. $\mathrm{Bu}$ sayede girişimcilerin yatırımları için para bulmaları kolaylaşmış, ulaşımdaki çarpıcı ilerlemeler, demiryollarının ve buharlı gemilerin geliştirilmesine paralel daha iyi karayollarının yapılması da pazarları genişletmiştir. Hızlı bir kentleşme içerisine giren Batı Avrupa'daki gelişmeler, malların fabrikalarda üretilmesi birçok kesim tarafından baş döndürücü olaylay olarak görülmeye başlanmıştır(Merriman,2018:564-575). "Avrupalıların, 19.yüzyılın ilk yarısında hızlı bir tempoyla meydana gelen ekonomik değişimden etkilenmemeleri mümkün değildi. Trenler uzak yerleri birbirine yakınlaştırarak, hakikaten ticarette ve seyahatte devrim yaptı. Şehirler hızla büyüdü; tren istasyonları, sermaye-yoğu çiftçilikle üretilmiş tarımsal malları daha büyük miktarlarda buralara taşıdı. Sanayide çalışan insan sayısı o zamana kadar görülmemiş ölçüde arttı" (Merriman,2018:621).

Sanayi devriminin ortaya çıkardığ 1 değişimi görebilmek için 1800'lü yıllardaki tarımsal ekonominin durumuna bakmamız ve daha sonraki gelişimi görmemiz yeterli olacaktır. 1800 yılında tarımsal ekonomi hem Avrupa'da hem de Avrupa dışındaki toplumlarda temel geçim modeliydi. Bununla birlikte Avrupa dışı ülkelerde örneğin Hindistan ve Çin'de de çok sayıda tüccar, tekstil üreticisi ve zanaatçı bulunmaktaydı. Bu ülkelerle Avrupa arasında kişi başı gelir farkları da çok fazla değildi. Örneğin el tezgahı kullanan Hintli bir dokumacı sanayileşmeden önce aynı işi yapan bir Avrupalının belki yarısı kadar kazanmaktaydı. Ancak sanayi devriminden kaynaklanan şaşırtıcı verimlilik artışı bu farkın oldukça fazla açılmasına neden olmuştur. 1750'li yıllarla 1830'lu yıllar arasında İngiltere'de yün eğirme alanında gerçekleşen makineleşmenin yalnızca bu sektördeki verimliliği 300-400 kat arttırdığı görülür. Bu tablo Avrupa'nın sanayileşme ile birlikte yaptığı sıçrayışı daha net ortaya koymaktadır(Kennedy,2008:190-191). Bir kapitalist modernleşme kimliğine bürünecek olan sanayi devrimi adımlarını hızlı bir şekilde atmaya başlamıştır. Önce iktisadi alanda oluşacak hegomenya, daha sonra siyasi ve düşünsel alanlarda da kendini gösterir(Touraine,2004:39). 
Avrupa'nın 1830-1913 arasındaki gayri safi milli hasılasında ülkeler bazında farklılık görünmekle birlikte ortaya koyduğu artış dikkate değer görünmektedir(Tilly,2005:165).

Sanayi devrimiyle birlikte oluşan sermaye birikimi, icatlar, sömürgelerden gelen ucuz hammadde ve yeni üretim pazarları uluslararası serbest ticareti tetiklemiştir(Ergüney ve Pilehvarian2015:224). Avrupa, sanayileşmenin ardından artan ürünlere pazar bulmak için imal ettiği ürünleri tanıtma ihtiyacı duymuş ve 1850'lerden sonra hakim duruma gelen kapitalist ağın ürünü olarak sergileme çalışmaları önem kazanmıştır. Temelde, ulusal olarak başlayan ve 1798 ile 1849 yılları arasında Fransa'da düzenlenen toplam on iki sergi, uluslararas1 sergilerin öncüsü niteliğindedir(Y1lmaz,2005:719). Her türlü ürünün teșhir edilerek var olan ticari potansiyelini artırmaya yönelik olarak organize edilen sergilerin uluslararası nitelik kazanması Fransa'daki öncü girişimlerin ardından XIX. Yüzyıl ortalarına rastlar (Keskin,2005:203).

Fransa'daki ulusal fuarları ziyaret eden İngiliz Devlet Arşiv Dairesi memurlarından Sir Henry Cole uluslararası fuarların kurucusu sayılır. İlk dünya fuarı Sir Henry Cole'ın önerisi doğrultusunda 1851 yılında İngiltere'de olmuştur. Hobsbawn tarafından “ Batı'nın kendini alkışladığı yeni ve büyük ayinler" olarak niteleyeceği bu fuarlar, küresel kapitalizmin Batı tarafından, nispeten artık küreselleşen dünyaya, gelinen ilerlemelerin boyutunun gösterilmeye çalışıldığı evrensel sergilerdir. Fuar yapıları önceleri geçici olarak düzenlenmiştir. Bu durum hızlı bir şekilde inşa edilme gereklilikleri nedeniyle sanayi devrimi sonrası ortaya çıkan inşaat malzemelerinin ve yapım tekniklerinin cesurca denenmesine de öncülük etmiştir. Gelen ziyaretçi sayısı ve dönemin yayın organlarındaki işgal edeceği yer onu, bu geçicilik temasının çok ötesine taşımıştır(Ergüney ve Pilehvarian,2015:225-228).

Klasik Osmanlı ekonomisi, Avrupa ülkelerinin izlediği seyri izlememiştir. Avrupa'da sanayi devrimine giden süreç ve sonrasında üretim ve ihracat faktörlerini Osmanlı'da göremeyiz. Üretim daha çok ülkenin kendi ihtiyaçlarını karşılamaya yönelik bir yol izlemektedir. Ordu için çalışan sanayi kuruluşları dışarıda bırakılacak olursa genellikle küçük ölçekli atölye ve imalathanelerden bahsetmek daha yerinde olacaktır(Önsoy,1988:7). 1850’lerden itibaren gerçekleşen uluslar arası sergiler, Osmanlı Devleti ile Batı arasındaki farkın açıkça görülmesini sağlayacaktır. Sergiler bu farkın kapatılması için yeni üretim tekniklerinin benimsenerek sanayileşmenin gerekliliğini de su yüzüne çıkarmıştır(Memiş,2015:53)

Uluslararası düzeydeki ilk Fuar olan 1851'deki Londra Fuarı'na Amerika, Fransa, İspanya, Portekiz, Rusya gibi ülkelerin yanı sıra Osmanlı Devleti de katılmıştır. Bu fuardaki Osmanlı pavyonunun*1 hemen yanında bağımsızlığını yeni kazanmış Yunanistan'ın olması ise trajik bir tesadüftür.1 Kasım 1850 tarihli Cerîde-i Havâdis gazetesinde belirtildiği gibi Osmanlı Devleti, bu ilk fuara katılarak topraklarının verimliliğini; tarım, sanat ve sanayideki başarısını ve padişahın, ülkenin başarısında gösterdiği gayreti ortaya koymayı amaçlamaktadır (Yılmaz,2005:719). Bu sergide, Kristal Saray'daki Osmanlı bölümünde ürünler vitrinlerde sergilenmiş ve alan çadır gibi kumaşla kaplanarak şadırvana benzer bir köşk de kurulmuştur. Sergide en fazla ilgi çeken ürünün de Bursa ipeği olduğunu görmekteyiz.(Göğüş,2007:38) Ancak Batılı ülkelerin gelişmelerini teknoloji, keşif ve buluşlar, endüstriyel makineler üzerinden sergilerken Osmanlı Devleti'nin geleneksel el sanatları, tarım ürünleri ve hammadde özelinde sergilemesi, Batı ile aradaki farklılığı gösterirken(Ergüney ve Pilehvarian,2015:228) bir başarı örneği teşkil etmekten uzak kalacaktır.

Daha sonraki uluslararası sergiler; 1853'teki New York, 1855 'te Paris ve 1862'de ikinci kez Londra'da olmak üzere açılan sergilerdir. Uzaklığı nedeniyle New York sergisine katılamayan Osmanlı Devleti, diğer sergilere iştirak eder (Keskin,2005:203).

19. yüzyılda Avrupa'da yaşanan iktisadi gelişmelere uzak durmak istemeyen Osmanlı, uluslararası sergilere iştirak etmeye gayret göstermiştir. Bu katılımdaki amaçlardan bir diğeri de,

\footnotetext{
1 İs.Fr.Pavillion.Bir kuruluşun,bir kurumun,bir bahçe içindeki yapılarından her biri.( Türk Dil Kurumu, Türkçe Sözlük, Ankara 1998, s.1179
} 
ülkedeki üretimlerin Avrupa'ya tanıtımıdır. Avrupa'daki örnekleri dikkate alınarak bu sergilerin yapıldığı ülkelere olan iktisadi faydaları İstanbul'da da bir serginin açılmasına önayak olur(Demir,2018:156). Osmanlı Devleti, 1863'te Sultan Abdülaziz döneminde, daha önce katıldığı ve tecrübe kazandığı sergileri model alarak İstanbul At Meydanı'nda "Sergi-i Umûmî-i Osmanî" adında, iç pazara yönelik bir sergi düzenlemiştir. Sergi yapıları Fransız mimarlar Marie-Augistin-Antonie Bourgeois ve Leon Prvillee tarafından tasarlanmıştır(Ergüney ve Pilehvarian,2015:229).

Üç kapılı ve dikdörtgen biçiminde tasarlanan 2500 metrekarelik sergi binasının ana girişinde üç kemerli revak üzerine "Sergi-i Umûmî-i Osmanî" yazısı yer almaktaydı(Haz.Işıklı,2012:32).Bu sergide önceleri yalnızca yerli ürünlerin sergilenmesi düşünülmüşken daha sonra bu serginin uluslararası bir nitelikte olmasına karar verilmiştir. Yabancı devletlerin davet edilmesinin ardından Fransa, İngiltere ve Avusturya-Macaristan çeşitli tarım makine ve aletleriyle bu sergiye katılmışlardır. Maliye Nazırı Mustafa Fazıl Paşa'nın başkanlığını yürüttüğü komisyonun, (Sultan Ahmet), At Meydanı'ndaki çalışmaları tamamlanmasının ardından sergi 28 Şubat 1863'te açılırken katılımına sonradan karar verilen yabancı heyetlerin bölümü 13 Nisan 1863 'te açılabilmiştir(Önsoy,1983:230). Söz konusu alet ve makinelerle zirai malzemeler sergi sonunda, kendilerine verilen tarım alanlarında kullanılmak üzere muhacirlere bağışlanmıştır(Yılmaz,2005:722).

Sergi için İmparatorluğun birçok vilayeti ve kazasından getirilen sanayi, tarım, dokuma, deri ve mobilya olmak üzere toplam 10 binden fazla ürün 13 ayrı bölümde sergilenmiştir(Haz.Iş̧1klı,2012:34). Başta, Abdülaziz olmak üzere diğer devlet büyüklerinin de açılışına bizzat katıldığı sergi 5 ay açık kaldıktan sonra Temmuz 1863 'te kapanmıştır. Sergiyi bu 5 aylık sürede yaklaşı olarak 100 ile 150 bin kişinin ziyaret ettiği tahmin edilmektedir(Keskin,2005:204).

1867'de Osmanlı Devletini Paris Dünya Fuarında görmekteyiz. Bu sergiyi Osmanlı açısından önemli kılan faktör Fransa İmparatoru Napolyon'nun daveti üzerine sergi açılışına Sultan Abdülaziz'in bizzat katılmasıdır. Fuar, Osmanlı Devleti'nin padişah düzeyinde katıldığg tek dünya fuarı olmasının yanı sıra, bir Osmanlı padişahının savaş olmaksızın imparatorluk dışına ilk çıkışı olması nedeniyle ayrıca önemlidir. Sergi nedeniyle Rus Çarı, Avusturya İmparatoru, Belçika, Portekiz, İsveç, Prusya Kralları ve Galler Prensi de Paris'e gelmiştir. Sultan Abdülaziz'e bu seyahatte Şehzade Murad, Abdülhamid ve Yusuf İzzeddin eşlik eder(Y1lmaz,2005:723-724).

1867 Paris Dünya Fuarı için ülkenin her köşesine haber gönderilerek mahalli sanayi ve tarım ürünlerinin en seçkinlerinin İstanbul'a gönderilmesi istenmiştir. $\mathrm{Bu}$ ürünlerin tespiti için kurulan komisyon ürünlerin sevk zamanını, cinsini ve miktarını organize etmekle görevlendirilmiştir. $\mathrm{Bu}$ çalışmalar sonucu sergiye gönderilmek üzere sanayi ve tarım ürünleri ile doldurulmuş 327 sandık ve iki kayık hazırlanmıştır. Tolanan bu eşyalar bir vapura sığmadığından iki grup halinde sevkiyat yapılmıştır. Çoğunluğu Mısır tarafindan gönderilmiş eşyalardan oluşan Osmanlı pavyonları çeşitli bölümlerden oluşur. Osmanlı'nın kültürel ve sosyal hayatını yansıtan birkaç bina tipinden oluşan pavyonda içinde bir cami bulunan bir alan olduğu gibi, bir Boğaziçi köşkü, bir hamam ve ortasında bir çeşmenin de olduğu mekanlar ziyaretçilere sunulmuştur(Tekdemir,2013:9-15). Bir bakıma tarihsel refaransların ve geleneklerin, pavyonların hazırlanışında dikkate alındığı görülmektedir.(Çelik,2005:69) Bu fuarda Osmanlı Devleti'nin temsil öğeleri olarak; halı, altın kaplı kumaşlar, lüks mobilyalar, ham işlenmiş ipek, silah, eğer, kundura, gümüş, demir, bakır vb. gibi ürünler sergilenmiştir. Bu sergide Osmanlı Devleti 100 kadar madalya ve mansiyon kazanır(Ergüney ve Pilehvarian,2015:231). Osmanlı Devleti'nin özellikle tarım ürünleri arasında Mısır pamuğundan aldığı birincilik kazınalan ödüller içinde ayrı bir yere sahip olmuştur (Tekdemir,2013:15).

Osmanlı Devletinin 1867'deki Paris Dünya Fuarı'nın ardından katıldığı fuarlara bakacak olursak; 1873 Viyana, doğrudan katılmamakla birlikte 1878 Paris, diğer ülkeler gibi Osmanlının da düşük katılımlı bulunduğu 1889 Paris ve 1893 Şikago Dünya Fuarlarını görürüz. Şikago Fuarını diğerlerinden ayıran ilginç bir ayrıntı vardır. Düzenleme komitesi Osmanlı Devleti'ne kendilerine milli bir bayram belirtmesini istediklerinde, Osmanlı Devleti'nde milli bir bayram bulunmaması nedeniyle 
yetkililer, fuar düzenleme komitesine milli bayram ve tarihi yerine geçeceğini düşündükleri bir tarihi: Padişahın cülus yıldönümü olan tarihi vereceklerdir.(Ergüney ve Pilehvarian,2015:238; Yazıc1(2005).

Osmanlı Devleti 1863'te düzenleği fuardan 30 y1l sonra yeni bir fuar düzenlemek için çalışmalara başlar. "Sultan II. Abdülhamit, fuarcılığın ekonomik kalkınma üzerinde etkisine inanıyordu. Bu nedenle hem yurt dışındaki fuarlara katılımı önemsiyor, hem de ülkenin merkez şehirlerinde ulusal sergiler düzenlettiriyordu. Bu kapsamda "memleketin servet ve refahının inkişafını teşvik" amacıyla İstanbul'da, 1863 "Sergi-i Umûmî-i Osmanî"den sonraki ikinci serginin yapılması talimatını verdi"(Haz.Işıklı,2012:134). Bu talimatın ardından 1893'te "Dersaâdet Ziraat ve Sanâyi Sergi-i Umûmîsi" adıyla bir sergi düzenlemek için komisyon kurulur. Komisyon başkanlığına da Selim Melhame getirilir. Komisyon üyelerinin seçimi yine Selim Melhame'nin nezaretindeki Orman ve Ma'âdin ve Ziraat Nezâretine, yani Selim Melhame'ye bırakılır.

Selim Melhame'nin Sicil-i Ahval'deki kaydında ilk görev yerinin daha yirmi bir yaşında, Şuray-1 Devlet Evrak Odası olduğunu görmekteyiz. Daha sonra bin dört yüz yirmi beş kuruş maaşla Suriye Vilayeti tercümanlığına tayini bulunmaktadır. Buradan istifa ettikten Hariciye Nezareti Muharrerat-1 Ecnebiye Kalemi'ne geçer. 93 seney-i hicriyesinde gönüllü olarak Sırbistan Savaşı'na katılan Selim Melhame, daha sonra 14 Ekim 1878 'de dört bin kuruş maaşla Rumeli Terakki Komisyonu Fransızca Kitabeti'ne tayin olur.13 Eylül 1879'da maaşinda tenzilata gidilerek 6 Kasım 1879'da Bulgaristan Komiserliği Maiyet Memurluğuna tayin edilecektir. Selim Melhame buradaki görevine başlamadan affını ister. 13 Ocak 1880 tarihinde altı bin kuruk maaşla Vergi İdaresinde müşavirliğe ardından 13 Ocak 1882'de yine aynı maaşla Divan-1 Umumiye müşavirliğine atanır. 25 Eylül 1883 'te maaşı yedi bin kuruşa çıkarılarak İrade-i Varidat Mahsusası Müdür Muavinliğine atanır. 13 Mart 1886 'da on üç bin yedi yüz elli kuruş maaşla Genel Müdür olan Selim Melhame 14 Mart 1892 tarihinde Düyûn-1 Umûmiyye Meclis İdaresi kararıyla görevden alınana dek bu makamda kalacaktır. 13 Şubat 1893 'te on beş bin kuruş maaşla tayin alacağ Orman Maadin ve Ziraat Nezareti görevini İstanbuldan ayrılacağı tarihe kadar muhafaza edecektir.(B.O.A, DH.SAİD.0072)

Lübnanlı bir avukat olan Başare (1824-1867) ve Suriye Ortodoks soyundan gelen İskenderiyeli Warda Al-Jarwa'nın (1835-1915) (Hanssen,2011:36) çocuğu olan Selim Melhame Osmanlı tarihi açısından son derece önemli bir dönemi kapsayan II. Abdülhamid dönemi içinde Sarayla kurduğu ilişki nedeniyle özel bir yere sahiptir.

1893'te kurulacak olan Orman ve Maden ve Ziraat Nezareti, tarımsal bürokrasinin nihai yapısına kavuşma tarihi olduğu kadar Selim Melhame'nin de II. Abdülhamid dönemi bürokrasisinde edineceği yerin sağlam bir temelini oluşturacaktır(Quataert,2008:84). Bir İngiliz belgesinde Selim Melhame, genç yaşta İstanbul'a gelen birçok devlet kurumunun alt kadamelerinde çalıştıktan sonra yükselmenin yolunun saraydan geçtiğini anlamakta gecikmeyen, kurnaz ve hırslı bir saray jurnalcisi olarak değerlendirmektedir (Kırmız1,1998:46).

II. Abdülhamid'in önem verdiği bir isim olan Selim Melhame'nin adının Düyûn-1 Umûmiyye'deki görevinin ardından Lübnan Mutasarrıflı̆̆ı için geçmesinde onun II. Abdülhamid'e olan yakınlığı etkili olmuştur. Sarayın referansında eski Düyûn-1 Umûmiyye Müdürü Selim Melhame'nin görev yaptığ 1 dönemde kendini ispatlamış ehliyet ve dirayet sahibi biri olduğu ve liyakatının da yabancılar tarafından onaylanmış olduğu söyleniyordu. Ayrıca Cebel-i Lübnan Mutasarrıflığına yerli bir ismin atanmasına karşı eleştiri de gelemeyeceği çünkü Selim Melhme'nin Lübnanlı olmayıp kendisinin Beyrutlu olduğu bilgisi ekleniyordu (BOA, İ.MTZ.CL, 7/308).

Bunun üzerine Eski Beyrut Valisi İsmail Kemal 23 Temmuz 1892 tarihinde gönderdiği telgrafta: Selim Melhame'nin Lübnan Mutasarrıflığı için adının geçtiği bilgilerinin Mısır'dan gelen gazetelerde yer aldığını, bu haberin de hem Beyrut'ta hem de Lübnan'da geniş bir şekilde yankılandığını söyler. Selim Melhame'nin Lübnanlı Maruni bir aileden olması ve Lübnan halkının, Fransa himayesinde görülen bu ailenin yönetimi altına girmek istemediğini açıkça ifade eden İsmail 
Kemal, Fransızların politik oyunlarına da sebep olacak bu atamanın yapılmaması gerektiğini bildirir(BOA, İ.MTZ.CL, 7/309).

Buradaki görevinin ardından adı Lübnan Mutasarrıflığı için geçmesine ve II. Abdülhamid'in desteğine rağmen o dönem gerek Fransız bürokrasisi içinden gerekse de içeriden gelen ve oldukça sert engellemeler onun bu göreve gelmesini önlemiştir. Ancak bu engel onun için daha başarılı bir yolun açılmasıyla sonuçlanır. 1893 Şubat'ından İstanbul'dan kaçacağı 1908 tarihine kadar yani yaklaşık olarak 15 yıl görevde olacağı bir bakanlığa atanacaktır: Yeni kurulan Orman, Maden ve Tarım Bakanıdır artık (Hanssen,2011:37).

Selim Melhame'nin 15 yıl nazırlık görevinde bulunmasını onun üstün zekasına bağlayan Kansu, bu süre içerisinde ülkenin doğal kaynaklarını koruma bahanesiyle madeni zenginliklerin gelişimini durdurarak önemli ölçüde şahsi menfaatleri doğrultusunda hareket ettiğini aktarır. Kansu, Selim Melhame'nin yabancı şirketlere verilmesine yardımcı olduğu imtiyazlar karşılığında aldığı komisyonlarla 30 milyon Frank'tan daha fazla bir gelir elde ettiğini de söylemektedir(Kansu,1995:179). Quatert da Selim Melhame ile ilgili benzer bir haksız gelir iddiasını Rouvier Projesi'nde gerçekleştiğini dile getirmektedir. 1902-1903 kamu borçlarının konsolidasyonu ile ilgili Rouvier Projesi gündemde olduğu dönemde bu projeye muhalif olanların başında Selim Melhame'nin geldiğini ve 7 ay blokelenen bu projenin ona verilen rüşvetle aşıldığını iddia eder. Padişahın hususi murahhası olarak Selim Melhame, konsolidasyonun şartlarını Alman Elçisi Marschall von Bieberstein ile görüşmektedir. Ancak Sadrazam Said Paşa'nın ve Rusya dışındaki diğer Avrupa devletlerinin desteğine rağmen proje Selim Melhame'nin başında bulunduğu grup tarafindan engellenmiştir. Verilen rüşvetle bu engelin ortadan kaldırıldığını aktaran Quatert, bu olaydan sonra Alman Elçisi'nin 9 Ocak 1903 tarihli raporuna göre de Selim Melhame, projenin gerçekleşmesi için padişahın önceki muhalefetini ortadan kaldırmaya yönelik girişimlerde bulunacaktır(Quataert,2008:85). Selim Melhame'nin II. Abdülhamid ile olan yakın ilişkisi nedeniyle Sadrazamlık makamını atlayarak doğrudan padişahla görüşüyor olması Sadrazam Said Paşa'nın amansız düşmanlığını kazanmasına da neden olmuştur(Kırmızı,1998:48).

Sergi görevi Selim Melhame'ye verilince o da bu iş için öncelikle bir komisyon teşkil eder. Dersaâdet Ziraat ve Sanâyi Sergi-i Umûmîsi adıyla ve Sultan Abdülhamid'in de isteği ve onayı ile (Yılmaz,2005:726) düzenlemesi düşünülen sergi için hazırlıkları yapacak olan komisyona Selim Melhame tarafindan seçilen üyeler şu isimlerden oluşur:

Ziraat Bankası Müdürü Cemal Bey, nezâret mektupçusu Abdüllatif Efendi, Mimar Valori, Müze-i Humâyûn Müdürü Hamdi Bey, Orman ve Ma'âdin ve Ziraat Hey'et-i Fenniyeleri reisleri Nazif, Ziya ve Aram Efendiler, Bahriyeden bir kişi ile Dersaadet Su Kampanyası Direktörü Silye(Keskin,2005:204-206). Bu isimlerden başka, kabul etmeleri durumunda İngiltere ve İtalya Büyükelçileri de komisyonda bulunabilecekti. Sergi nâzırı, komisyon dışında, memur mühendis ve hademenin tayinlerinden, eşyalarla ilgili tüm resmi dairelerle yapılacak görüşmelerden, gönderilecek eşyaların kabulü için oluşturulacak heyetlerden de sorumlu olacaktı.

"Sergide teşhir edilecek eşyalar iki ana şubeye ayrılmıştı. Her şube üç kısma, kısımlar da kırkyedi sınıfa ayrılmıştı. Ziraat mahsulleri, baharatlar, maden mamulleri, sebze ve meyveler, orman ürünleri, ziraat eğitiminde ve çiftlikte kullanılan alet, edevât ve istatistikler, avcıllk ve balıkçıllk ürünleri deri mamulleri ve bu alanda kullanılan aletler, büyük ve küçük baş hayvan çeşitleri, özel olarak yetiştirilen hayvanlar ve daha bir çok ürün birinci şubede yer alacaktı. İkinci şubede ise kimya, eczacılık, tekstil ve deri sektöründe kullanılan alet ve makineler, elektrik, nafia, ve mimarlıkla ilgili aletler ile saatçilik, kuyumculuk, marangozluk, sepetçilik halı, kilim, keçe örnekleri yer alacaktı" (Keskin,2005:204-206).

19 Ekim 1893 tarihli irade ile resmiyet kazanan Sergi nizamnamesinin ardından keşif çalışmaları başlar. Sergi alanı için Şişli'deki İzzet Paşa Çiftliği ile Dârulaceze arasındaki alan değerlendirilmek istenmiştir. Yapılacak bina için iki yabancı mühendis ve mimara başvurulur: "İtalyan 
Mimar Raimondo D’Aronco (Y1lmaz,2005:726) ve Fransız Mühendis Kovil. D'Aronco. Sergi binasının plan ve resimleri Eylül 1894'te bitirilir. Mühendis Kovil, sergi binasının inşaat kısımlarıyla ilgilenecektir. Kovil'in planlarında binanın duvarları taş ve tuğladan, çatı ve diğer yerler de cam ve çinko ile kaplanacaktı. Çatı üzerinde kuleler ve bina etrafında da balkonlar olacaktı. Tüm bunlar için de 6340 liralık bir harcama öngörülmüştü(Keskin,2005:207). II. Abdülhamid'in "tesis ve küşad" etmeyi düşündüğü bu serginin faklı bir özelliği bulunacaktı. Bu sergi geniş bir alana, sabit binalar yapılarak meydana getirilecekti. Sultan tarafindan bir sergi açma hevesinden çok, ülke kalkınmasına hizmet gayesi güdülüyordu(Memiş,2015:279)

Söz konusu serginin milli bir sergi olması nedeniyle, açıldığında memleketin ürünlerinin mahsulatıyla toplanacak eşyaların sergilendikten sonra yapılacak bina atıl duruma düşürülmeyip daimi bir sergi halinde kalacaktır. Sergi yalnızca senenin en soğuk mevsiminde dört ay kapalı kalacak, diğer sekiz ay ise açık tutulacaktır. Bu süre içinde de diğer devletlerde olduğu gibi bir panayır havasında olacak ve her ay bir ürünün ya da eşyanın teşhiri için ayrılacaktır. Bu şartlar göz önünde tutularak binanın taksimatının ona göre yapılması konusunda baş kitabetten uyarıda bulunulur. Yine bu uyarıda, İtalya'daki Milan, Palermo ve Torino sergilerine bakılmasının yanında buralarda yapılan sergilerin yapılacak sergi binasının yapım özelliklerini karşılamama olasılığının bulunabileceği, böyle bir durumda, Orman ve Maden ve Ziraat Nazırı Selim Melhame'nin yaptırmış olduğu planların da dikkate alınabileceği yönünde telkinler yapılmıştır. İnşaat süresinin iki sene içerisinde tamamlanarak açılışa hazır olması, taş ve tuğla ağırlıklı kısmın İzzet Paşa Çiftliği yakınındaki taş ocaklarından, demir ihtiyacının, Sultan Abdülaziz tarafından Tersane-i Amire fabrikalarında gayet sağlam limonluk yaptırıldığı örneği ile tersaneden ve Bahriye Nazırlığından iş̧̧i teminiyle masrafların azaltılabileceği yönünde tavsiyeler de dikkate değer yönlendirmelerdir(BOA.İ.DUİT 00136).

Sergi ile ilgili mali hazırlıklara gelinecek olunursa, burada Selim Melhame'nin oldukça detaylı hazırlanmış olduğu bir rapor karşımıza çıkmaktadır. Bu raporda Selim Melhame, çeşitli gelir kaynaklarını göstererek buradan elde edilecek gelirlerle sergi masraflarının karşılanabileceğini belirtmektedir. Selim Melhame'nin sunduğu raporda:

* Düyûn-1 Umûmiyye tarafından alınmakta olan Ulaştırma, inşaat ve tamir gibi verilen izin belgelerinden alınan harç, Bağdat ve bazı bölgelerde alınan esnaf harcı ve belediyeye bağlı birimlerce alınan beş kuruşluk harcın artırılması

*İstanbul'da imar izinlerinden alınan harç oranlarının artırılması

*İstanbul'da balık vb gibi deniz ürünlerinden alınan harçların artırılması

*Sefain, ağnam, seyd ve şibar gibi harçlardan alınan ve Düyûn-1 Umûmiyye tarafından hazineye aktarılan kısımlardan alınan yüzde beşlik kısmının artırılması

*Girit'e ithal edilen yabanc1 tütünlerden ve ispirtolardan yıllık bört- beş bin lira olan gelirlerden ve adalara gönderilen ispirtolardan, yine Gelibolu, Marmara, Gemlik ve Tekirdağ bölgelerinde yerel birimlerce alınan harcın hazineye aktarılması

*Kaçakçıllk ve kaçak ürünlerle mücadele için Bahriye Nezaretinden alınarak kullanıma sunulan gemiler için harcanan masraflardan arta kalan ve tütün vb. mamüllerin satışından bölge idarelerine kalan iki bin liranın artırılması

*Anadolu ve Manastır Demiryolu hatları için teminat olarak ilgili bölgelerden Osmanlı Bankası aracılığı ile alınmakta olan aşar gelirinden elde edilen faizin artırılması

*Bölge idarelerinin, Lübnan'dan yapılan tuz ihracından elde edilen ürünlerden alınan yaklaşık on iki bin liradan mümkün olan kısmının hazineye aktarılması(BOA İ.DUİT 00136)

Gibi maddeler bulunmaktadır. Hem maliye hem de deftardarlık tarafindan incelenen maddelerin, genellikle Düyûn-1 Umûmiyye İdaresine ayrılan gelirleri kapsıyor oluşu ve buradan yapılacak kesintilerin Düyûn-1 Umûmiyye İdaresince hoş karşılanmayacağı gibi bunun yanında bazı 
vergilere yapılacak zamların halk tarafından da tepkiyle karşılanabileceği belirtilmiştir. Buna ek olarak ayrıca, bu artışların yapılması halinde bile söz konusu harcamalardan kesintiyle elde edilecek tutarın yapılacak serginin masraflarını karşılayamayacak durumda olduğu söylenmiş ve alternatif gelir unsurları teklif edilmiştir. Bu tekliflere bakacak olursak:

*Haydarpaşa ile Pendik arasındaki istasyonları kullanan yolculardan alınan tarifeye bir miktar zam yapılması, diğer istasyonlarda satılan biletlerden bedeli altı kuruştan on beş kuruşa kadar olanlardan on para; on altı kuruştan yukarı olan biletlerden de birer kuruş alınabileyeği. Bu şekilde, Haydarpaşa Şimendifer Kumpayası'dan senelik yüz elli bin dört yüz elli beş kuruş gelir sağlanacağı

*Rumeli Demiryolları biletlerinin beş kuruşluktan on kuruşluğa kadar olanlarından on; on kuruşluktan yirmi kuruşluğa kadar olanlarından yirmi para; yirmiden elliye kadar olanlarından iki; elliden yüze kadar bulunanlardan beş; yüzden elliye kadar olanlarından on iki; iki yüzden yukarısından yirmi kuruş alınmak şartıyla senelik dört yüz elli bin yedi yüz otuz kuruş elde edileceği

*Tramvay şirketinden senelik iki yüz elli altın alınması

*İdare-i Mahsusaca Haydarpaşa - Kadıköy, Kalamış hatlarıyla Pendik’e kadar adalara gidişgeliş yapan vapurların dönüş ücretleri eskiden olduğu gibi alınarak çavuş rütbesine kadar olan 20 paralık biletler sabit kalmakla birlikte, yalnız köprüden gidiş için Zâbıtân-1 Askeriye ve sair yolculara ait normal mevki biletlerin her birine onar para zam yapılması durumunda buradan senelik üç yüz bin kuruş gelir sağlanacağ 1

*Şirketi Hayriye'ye gelince, daha önce olduğu gibi Sim-i Mecidiyenin*² on dokuz kuruşa alınıp verilmesine ve şartnamenin kırkıncı maddesi hükmünce Boğaziçi’nin iki taraf sahilinde ikinci ve üçüncü hat olarak tanımlanan bölgelerdeki insanların sürat ve suhuletle gidiş gelişlerini temin için sabahın tuluğ vaktinden saat dört buçuğa kadar yukardan köprüye ve akşamları saat dokuzdan on bir buçuğa kadar köprüden yukarıya doğru giden vapurların miktarı, bu sene yaz ve kış mevsimlerinde icra k1lınan seyr ü sefer tertiplerindeki adetten noksan olmamak ve ilerde ihtiyaç hasıl olur ise daha artırılarak seferlerin tertip ve icra kılınmasına ve yolcuların iş zamanlarına göre seferlerin şirket tarafindan ihtiyaca göre organize edilmesi

*Rumeli sahilinde Beşiktaş'tan Rumeli Kavağına ve Anadolu tarafindan dahi Kuzguncuk'tan Anadolu Kavağı'na kadar olan iskelelerde her gün yalnız köprüden verilen biletlerle iskeleden iskeleye gidiş ve dönüşe mahsus biletlerin günlük muayyen olan bedelleri üzerine Hükümet-i Seniyye nam ve hesabına olmak üzere onar pare zam yapıldığı halde dört taksit ile Hükümet-i Seniyye'ye senelik altı yüz yirmi beş bin kuruşun gelir sağlanacağı; ancak bu zammın geri alınması durumunda, yani şirketin bu meblağı ödeme zorunluluğundan kurtulması durumunda, şirket vapurlarında mecidiyenin on dokuz kuruşa kabulü müsaadesi mukabilinde şirketin Darülaceze'ye senelik beş yüz lira vermesi. Bununla birlikte zammın tamamen geri alınmayıp da kısmen uygulanması durumunda ise kalan miktarın iskeleleri kullanan yolculardan tahsili yöntemiyle gelirin altı yüz yirmi beş bin kuruştan az olmaması sağlanabilir. Bu tutarın üzerinde bir tahsilatın yapılmaması ve yapılacak zammın şartname gereği uyarınca Askeri, Sanayi, Rüşdiye ve Darüşşafaka mekteplerindeki öğrenciler ile askeriye personelinden başçavuşa kadar olanlara özgü on ve yirmi paralık biletleri kapsamamasının kararlaştıldığına

* Bahsi geçen şirket ve idarelerden topanacak gelire baktığımızda bunların tamamı senelik bir milyon beş yüz elli bin küsür kuruş olmakla birlikte gerek Düyûn-1 Umûmiyye gerekse bahsedilen bu diğer şirketlerden sağlanacak tutarın başka bir şekilde teminin de mümkün olduğu ve bunun bir krediyle sağlanabileceği, bir kredi anlaşması yapılarak borçlanılan akçeyle söz konusu serginin masraflarının karşınabileceği gibi öneriler sunulacaktır (BOA İ.DUİT 00136).

\footnotetext{
${ }^{2}$ Yirmi kuruş değerinde gümüş sikke
} 
Ancak yapılan tüm hazırlıklar 1894'te İstanbul'da meydana gelen büyük depremle boşa çıkacaktır. 1894'te açılması düşünülen ve başta ulusal olarak planlanıp sonra uluslararası bir sergi olması kararlaştırılan bu sergi 1894 depremi nedeniyle gerçekleştirilemeyektir. "1894'te İstanbul'u sallayan şiddetli deprem ağır hasara yol açar ve sultanı projesinden vazgeçip deprem felaketinde hasar gören yapıların onarımıyla uğraşmak zorunda bırakır. O zaman D'Aronco birçok kamu binasını, camileri, hastaneleri, okulları restore etmekle görevlendirilir; ayrıca depremde çok hasar gören Kapalıçarşı'nın onarım çalışmalarına da katılır. D'Aronco İstanbul'daki onarım çalışmalarını sürdürürken, Yıldız'da da birçok mimari esere imzasını atar. Bu eserlerde giderek belirginleşen bir "Art nouveau" üslubu görülmektedir: Küçük Mabeyn'in karşısındaki sevimli seralar, Harem'in bahçesindeki diğer limonluk ve seralar, 1898'de II. Wilhelm'i ağırlamak üzere Şale Köşkü’ne eklenen Merasim Köşkü,tiyatro, Yeni Saray adı verilen köşk, İstabl-i Âmire'nin ahırları ve maneji,"Belle Epoque" üslubunda yapılmış Yaveran dairesi ve onun üslubunun özgünlügünü herhalde en iyi ifade eden yapı olarak, araya beyaz taşlar ve çini süslemeler serpiştirilmiş silme kırmızı tuğlayla kaplanmış kırmızı tuğlayla kaplanmış Çini Fabrikası.Ayrıca Yıldız Sarayı yakınındaki, Osmanlı Art nouveau'sunun başyapıtlarından Şeyh Zafir Madani Türbesi'nin ve Şaziliyye Tekkesi'nin de mimarıdır" (Georgeon,2006:152) Raimondo D'Aronco 1895 ile 1909 arası saray mimarı olarak birçok yapının onarılmasında görev almıştır.

\section{Sonuc}

Osmanlı Devleti, sergileri, özellikle ekonomik ve kültürel değerlerini tanıtma amacı olarak görmüştür. Sergilerin uluslararası boyut kazandığı 1851 Londra Sergisinden başlamak üzere daha sonraki katılacağı sergilerde de kültürel kimliğini göstermekten geri durmamıştır. Devletin; tarımsal, zirai, zanaat ve toplumsal birikimleri sergile gayreti 1863 'te uluslararası bir sergi düzenleme faaliyetiyle neticelenecektir. Bundan sonraki sergilere de Osmanlı'nın ilgisini özellikle 1867 sergisine bizzat padişahın katılmış olması ile daha net bir şekilde görmekteyiz. Sultanaziz döneminden II Abdülhamid dönemine kadar geçen dönem, sanayi alanındaki girişimlerin devam ettiği, ülkede faaliyet gösteren yerli ve yabancı şirketlere teşviklerin artırıldığı bir dönem olarak devam etmiştir. Fuarlara ilk andan itibaren önem veren Osmanlı Devleti, fuarlara devlet görevlilerini de göndererek raporlar tutturup değerlendirmeler yapmıştır.

II Abdülhamid dönemini sergilerin önemini koruduğu bir dönemdir. $\mathrm{Bu}$ dönemde kurulan ticaret odaları da kalkınma için sergiyi özel bir yere koyar. Bu anlayış, Avrupa'nın hasta adam olarak gördüğü Osmanlı'nın, başta büyükşehirler olmak üzere ülke çapında büyüyen bir ekonimi, istihdam ve üretim faaliyetlerini gösterme arzusunu kamçılamıştır. Osmanlı, Uluslararası sergileri ekonomik açıdan olduğu kadar siyasi açıdan da önemsemektedir. 1889'daki Paris sergisinin Uluslararası yakınlaşma ve barış açısından önemli görülmesi bu bakışaçısını güçlendirir. Yine II. Abdülhamid'in 1893 Chicago Sergisi'ne yaklaşımı da benzer nedenler barındırır. Bununla birlikte II. Abdülhamid, sergileri bir imaj unsuru olarak görmüş ve yaklaşımı da bu doğrultuda olmuştur. Ekonomik ve siyasi nedenlerle katılınamayan 1878 ve 1879 'daki sergiler ve yine ekonomik gerekçeler sunularak katılım gösterilmeyen 1904 Lousisiana Dünya Fuarı dışında sergi iştiraklerine özen gösterilmiştir.

II. Abdülhamid'in güvendiği isimlerden biri olan Orman ve Ma'âdin ve Ziraat Nazırı Selim Melhame'yi kalıcı bir sergi yapımı için görevlendirmesinin altında yatan gerekçenin sergi ve fuar kavramlarının önemini bilen ve bunu kullanmak isteyen irade olduğu açıktır. Selim Melhame, çıkarılan irade doğrultusunda çalışmalar yürütmüş ve serginin hizmete açılması için gerekli maddi kaynakların temini doğrultusunda raporlar hazırlayarak bunları ilgili kurumlara sunmuştur. II. Abdülhamid'in yakından takip ettiği sergi çalışmaları 1894 İstanbul depremi nedeniyle iptal edilmiştir. Ancak sergi nedeniyle göreve başlayan mimar Raimondo D'Aronco'nun bu sefer depremin verdiği zararları gidermede görevlendirilmesi ve başarılı çalışmalar yapması başlanılan sergi faaliyetinin Osmanlı'ya kazanımı olmuştur. 


\section{Kaynakça}

BOA İ.DUITT 00136

BOA, DH.SAİD.0072

BOA, İ.MTZ.CL, 7/308

BOA, İ.MTZ.CL, 7/309

Çelik, Z. (2005). Şarkın Sergilenişi, Tarih Vakfı Yurt Yayınları

Demir, K. Y. (2018). Sergi-i Umumi-i Osmani’nin (1863) Aç1lışı ve Serginin Duyurulmasında Gazetelerin Rolü, Firat Üniversitesi Sosyal Bilimler Dergisi, 28(1), 155-169

Ergüney, Y. D. ve Pilehvarian, N. K. (2015) Ondokuzuncu Yüzyıl Dünya Fuarlarında Osmanlı Temsiliyeti, Megaron, 10(2), 224-240

Georgeon, F. (2006). Sultan Abdülhamid, Çev. Ali Berktay, Homer Kitabevi Yay.

Göğüş, C. (2007), 19. yy Avusturya Gazeteleri Işı̆̆ında Osmanlı Imparatorluğunun 1873 Viyana Dünya Sergisine Katılımı, Yayımlanmamış Yüksek Lisans Tezi, İstanbul Teknik Üniversitesi, Fen Bilimleri Enstitüsü.

Yılmaz, G. (2005). Osmanlı Devletinin Katıldığı Uluslararası Tarım, Endüstri, Sanat Sergileri ve “Iâne Sergisi”, Sinan Genim'e Armağan Makaleler, 718-730

Hanssen, J. (2011). "Malhame-Malfame":Levantine Elites And Transimperial Networks on the Eve of the Yong Turk Revolution", International Journal of Middle East Studies, 43, 25-48

Haz. Işıklı, A. (2012). Türkiye Fuar Albümü, Osmanlı Dönemi, İfm

Kansu, A. (1995). 1908 Devrimi, İletişim Yayınları

Kennedy, P. (2008). Büyük Güçlerin Yükseliş ve Çöküşleri, Türkiye İş Bankası Kültür Yayınları

Keskin, Ö. (2005). Orman Ve Ma'âdin Nezâreti'nin Kuruluşu ve Faaliyetleri, Yayımlanmamış Doktora Tezi, İstanbul Üniversitesi, Sosyal Bilimler Enstitüsü.

Kırmızı, A. (1998). II. Abdülhamid Dönemi (1876-1908) Osmanlı Bürokrasisinde Gayrimüslimler, Yayımlanmamış Yüksek Lisans Tezi, Hacettepe Üniversitesi.

Memiş, Ş. (2015), 19. Yüzyılda Bir Sanayileşme Stratejisi Olarak Uluslararası Fuarlar: Osmanlı Örneği, Yayımlanmamış Doktora Tezi, İstanbul Üniversitesi, Sosyal Bilimler Enstitüsü.

Merriman, J. (2018). Rönasans 'tan Bugüne Modern Avrupa Tarihi, Say Yayınları

Önsoy, R. (1988). Tanzimat Dönemi Osmanlı Sayanii ve Sanayileşme Politikası, Türkiye İş Bankası Yayınlar1

Tekdemir, A. (2013). ” 1867 Paris Sergisi ve Sultan Abdülaiz'in Sergiyi Ziyareti”, Trakya Üniversitesi Edebiyat Fakültesi Dergisi, 3(6), 1-19. 
Ek1. Osmanlı Devleti'nin düzenemiş olduğu 1863 Sergi-i Umûmî-i Osman̂̂’’den( Haz.Işıklı, A,2012:32)

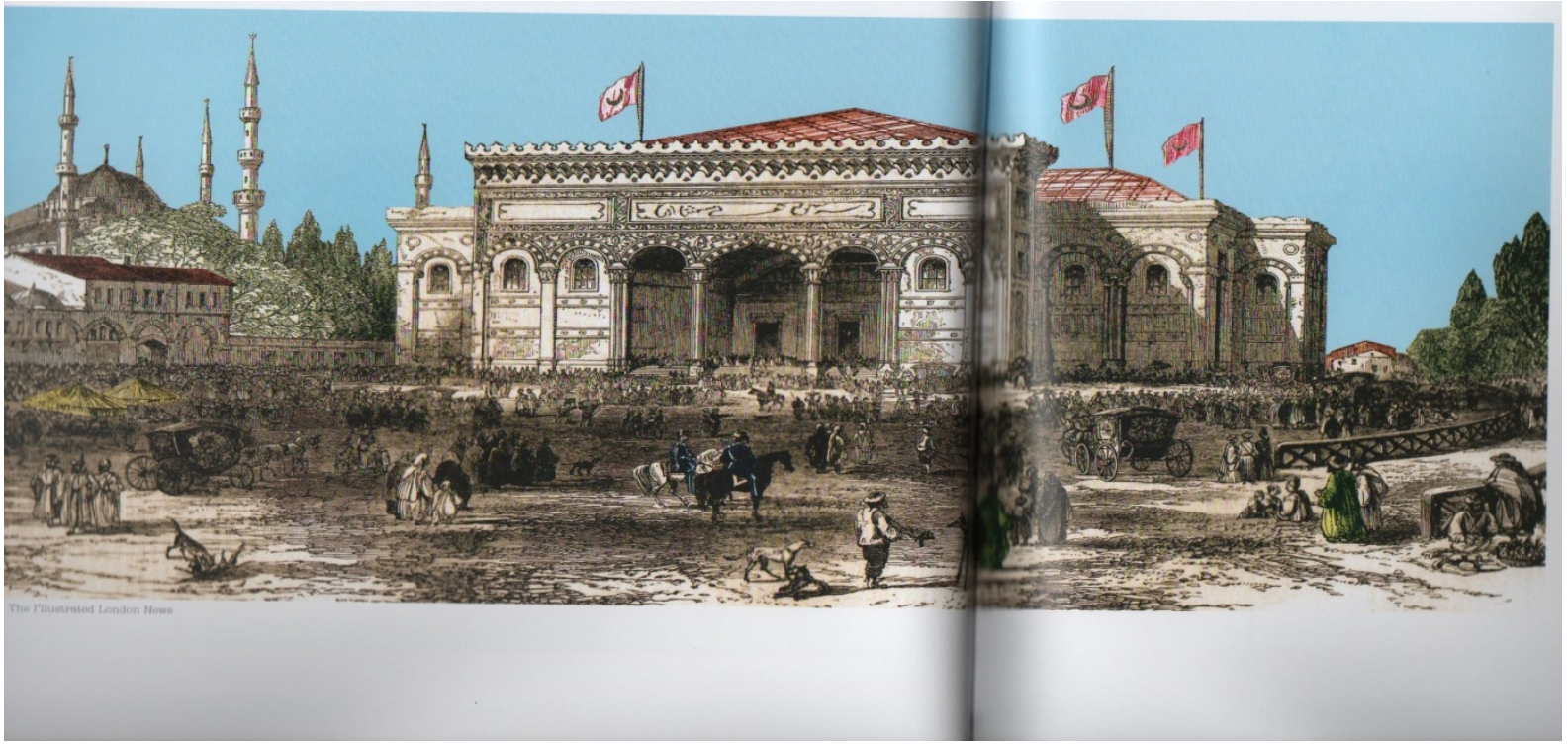

Ek2. Osmanlı Devleti’nin düzenemiş olduğu 1863 Sergi-i Umûmî-i Osmanî’’den (Haz. Iş1klı, A,2012:34)

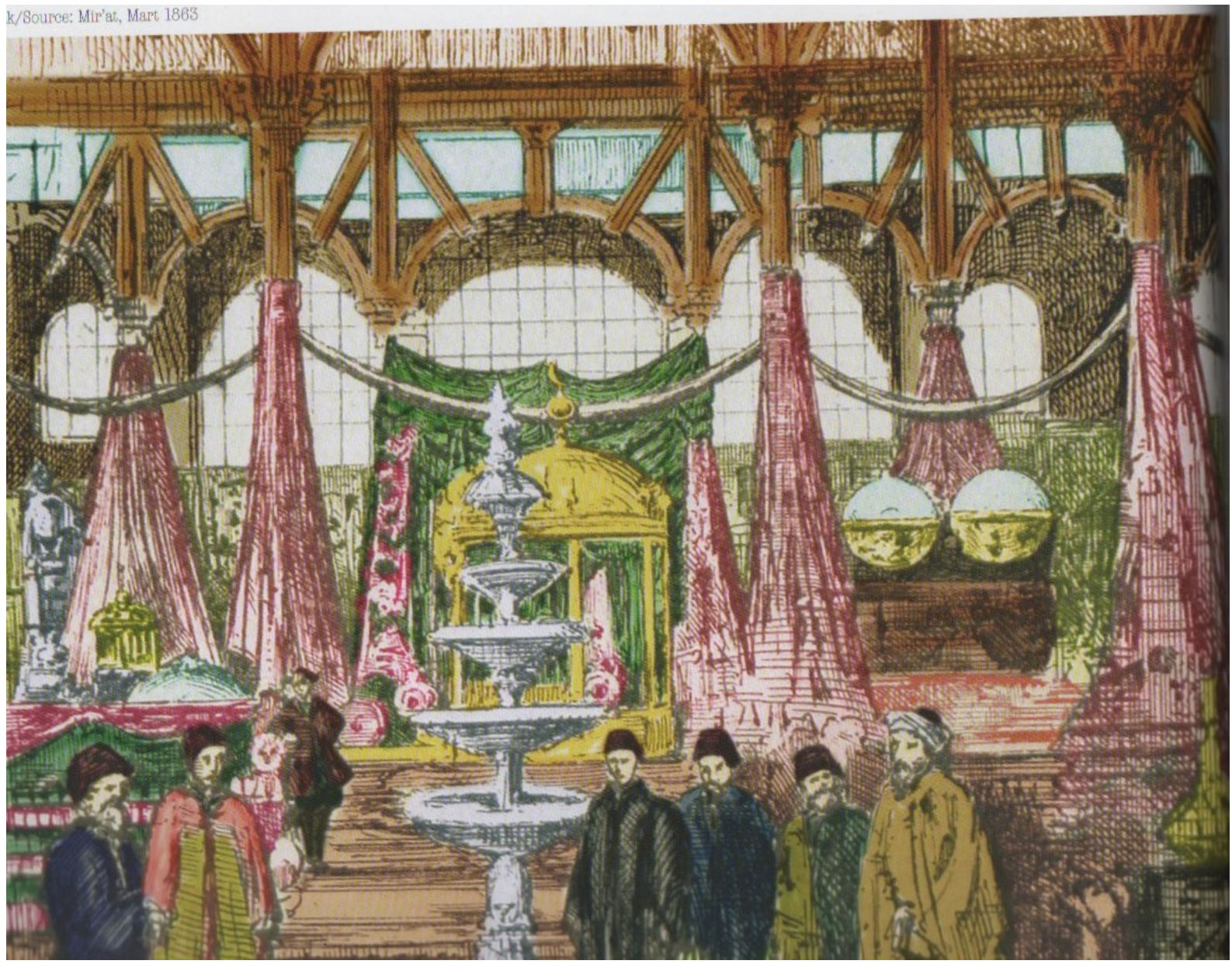


Ek3. 1867 Paris Sergisinde kurulan Türk Köyü (Haz. Işıklı, A,2012:36)

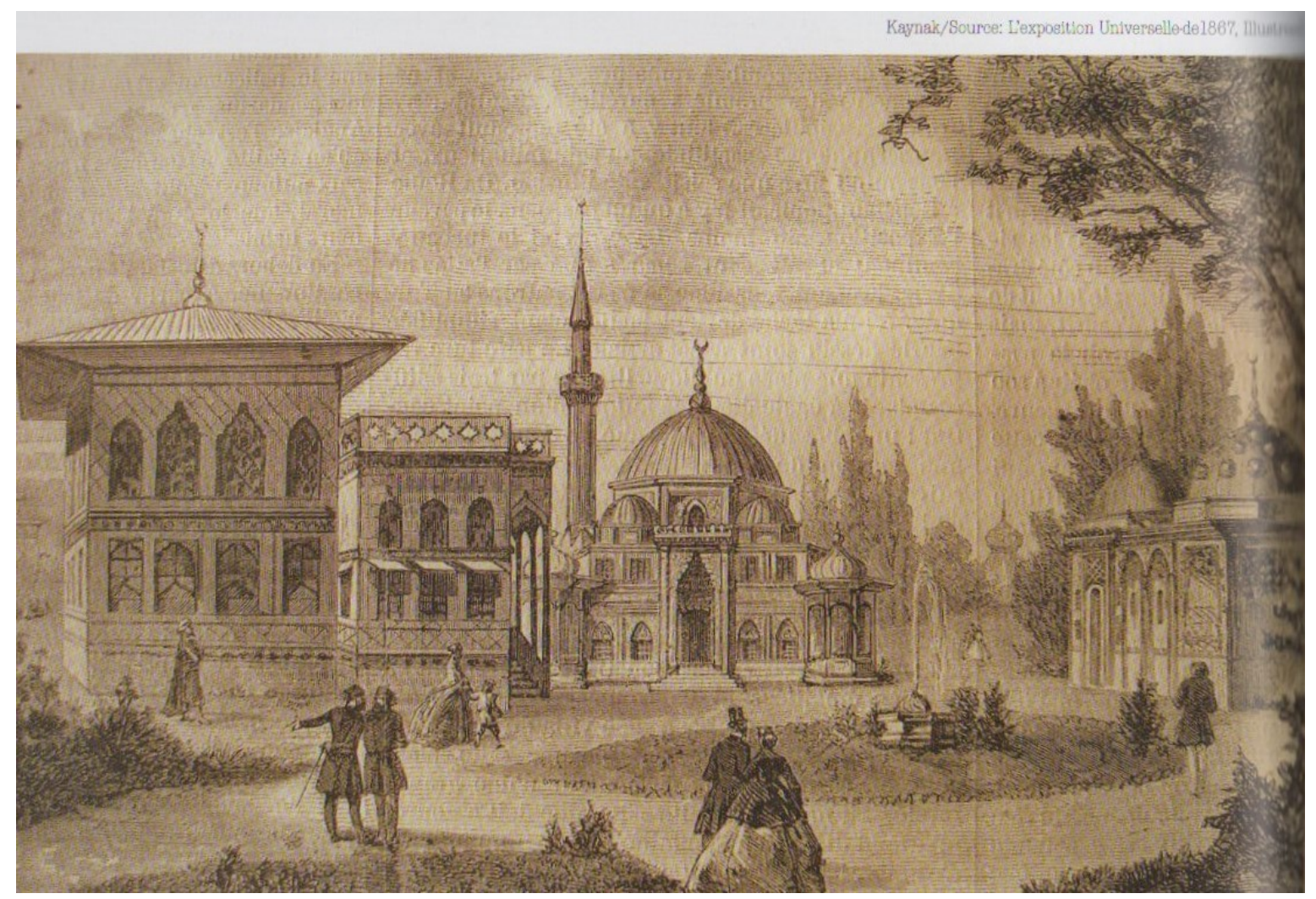

Ek4. Mimar D’Aranco 1893-1909 İstanbul Projelerinden bir örnek (Haz.Işıklı, A, 2012:136137)

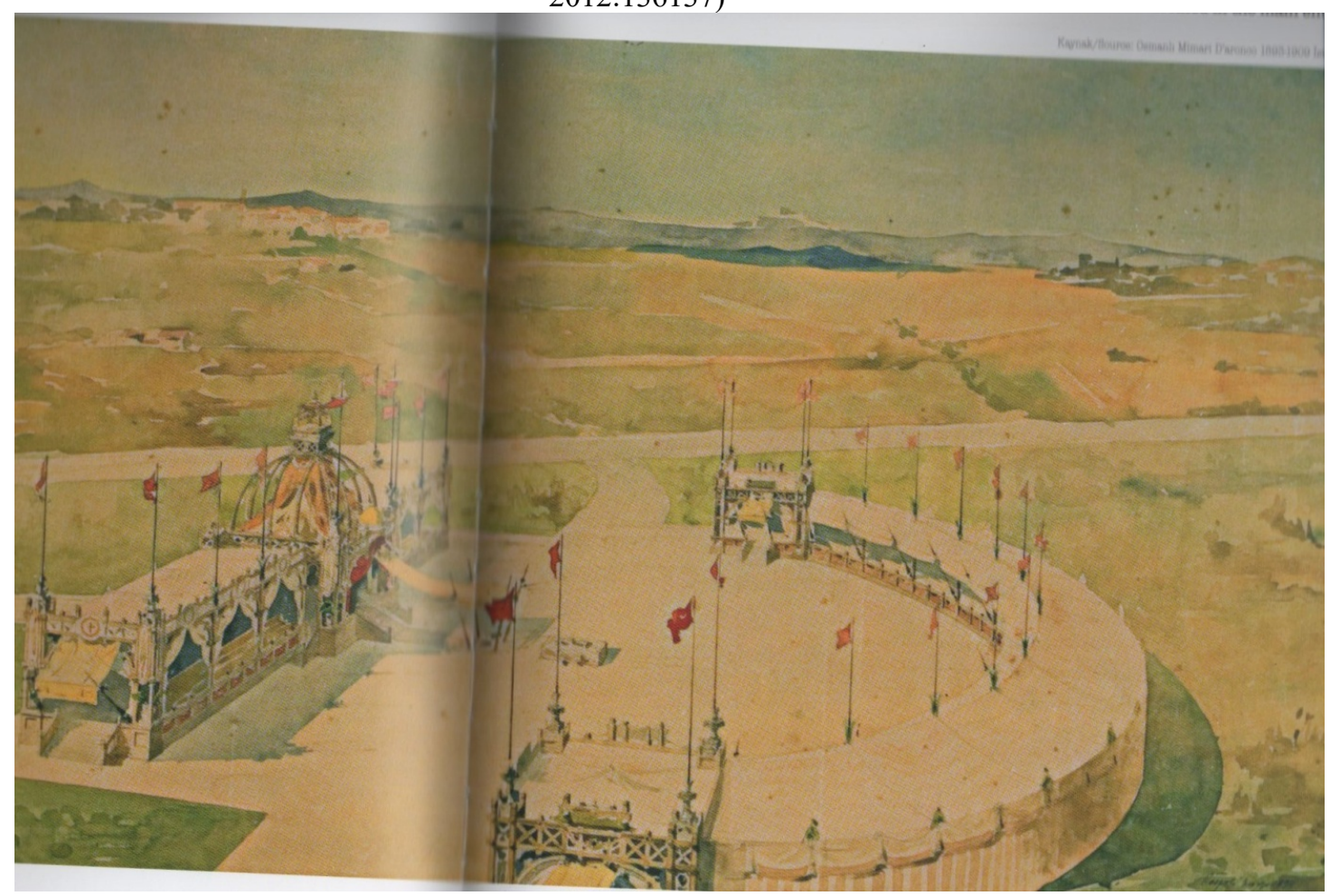

